\title{
Facial nerve palsy associated with leptospirosis
}

\author{
Paralisia facial associada à leptospirose \\ Everaldo Costa ${ }^{12}$, Edilson Sacramento ${ }^{12}$, Antonio Alberto Lopes ${ }^{3}$ and José Carlos Bina ${ }^{3}$
}

\begin{abstract}
This case report describes the findings of a 27-year-old black male from Bahia, Brazil, who developed facial palsy during the convalescence phase of leptospirosis. The patient recovered without neurological sequel. This work calls attention to a possible association between leptospirosis and facial palsy.
\end{abstract}

Key-words: Leptospirosis. Facial palsy.

Resumo Este relato de caso descreve os achados de um homem de 27 anos, residente na Bahia, Brasil, que desenvolveu paralisia facial durante a fase de convalescença da leptospirose. O paciente se recuperou sem sequela neurológica. Este trabalho chama atenção para uma possível associação entre leptospirose e paralisia facial.

Palavras-chaves: Leptospirose. Paralisia facial.

For a relatively large percentage of patients who develop acute facial nerve palsy, no cause is identified. There is evidence, however, that infections play an important role in the development of the problem 2456789 . The current list of infections reported as possible causes of facial palsy is relatively large ${ }^{9}$. Even though facial palsy has been found in patients with spirochetal diseases ${ }^{1}$, only one previous study described this problem in a patient with leptospirosis ${ }^{11}$. The present case report presents the clinical findings of a patient with leptospirosis, who developed facial palsy in the course of the disease. The work was approved by the ethics committee of the Couto Maia Hospital. The patient signed a consent form to show his photograph in this publication.

\section{CASE REPORT}

A 27-year-old black male, street vender, was admitted on May $18^{\text {th }} 1998$, to an infections disease hospital (Couto Maia Hospital) located in the city of Salvador, Northeast Brazil, during an outbreak of leptospirosis. He was well until six days before hospitalization when fever, chills, headache, vomits, prostration and generalized severe myalgia, particularly in the calves, developed abruptly. On the fifth day of symptomatic disease, icterus was noticed. The patient referred the existence of rats in the backyard of his house that was flooded by rain water a few days before the onset of the disease. On admission the patient was found to be profoundly icteric (IV/IV) with conjunctival hyperemia, typical of leptospirosis. The pulse was 108 and regular, temperature was $37^{\circ} \mathrm{C}$, blood pressure was $70 / 30 \mathrm{~mm} \mathrm{Hg}$ and respirations were 32 . He complained of intense tenderness caused by palpation of calves and abdomen. There was no sign of meningeal irritation. The initial laboratory examination showed serum urea of $247 \mathrm{mg} / \mathrm{dl}$ and creatinine of $5.8 \mathrm{mg} / \mathrm{dl}$.
The aspartate aminotransferase was $70 \mathrm{mg} / \mathrm{dl}$, alanine aminotransferase $28 \mathrm{mg} / \mathrm{dl}$ and serum albumin $2.5 \mathrm{~g} / \mathrm{dl}$. The total bilirubin reached a level of $55.2 \mathrm{mg} / \mathrm{dl}$ (direct bilirubin was $38.1 \mathrm{mg} / \mathrm{dl}$ ). The total white blood count was $13,100 / \mathrm{mm}^{3}$ (neutrophils was $98 \%$ ), platelet $126,700 / \mathrm{mm}^{3}$ and hematocrit 34\%. Urinalysis showed proteinuria $(+++)$ and red cells. Exam of the cerebrospinal fluid was not performed. The macroagglutination test for leptospirosis was performed on different days. The first exam was negative (May 19 ${ }^{\text {th }}$ ) and the subsequent ones (May $21^{\text {th }}$ and $25^{\text {th }}$ ) were positive. The patient was volume expanded and despite his acute renal failure being nonoliguric he was submitted to peritoneal dialysis. On June 1, when he was considered to be ready for hospital discharge, a right side facial nerve palsy (Figure 1A) was diagnosed. Prednisone was administered $20 \mathrm{mg} /$ day and the patient was discharged 24 hours later. On June 27, the patient was seen at the ambulatory. No sign of facial palsy was observed at that time (Figure 1B).

\footnotetext{
1. Department of Medicine, Escola Bahiana de Medicina e Saúde Pública, 2. Departament Infectious Disease, Hospital Couto Maia, 3. Department of Medicine, Universidade Federal da Bahia, Salvador, BA.

Address to: Dr. Antonio Alberto Lopes. R. Marechal Floriano 448/1301, Canela, 40110-010 Salvador, BA, Brasil.

Tel: 5571 336-1558, Fax: $5571245-7110$

e-mail: aaslopes@ufba.br

Recebido para publicação em 18/4/00.
} 


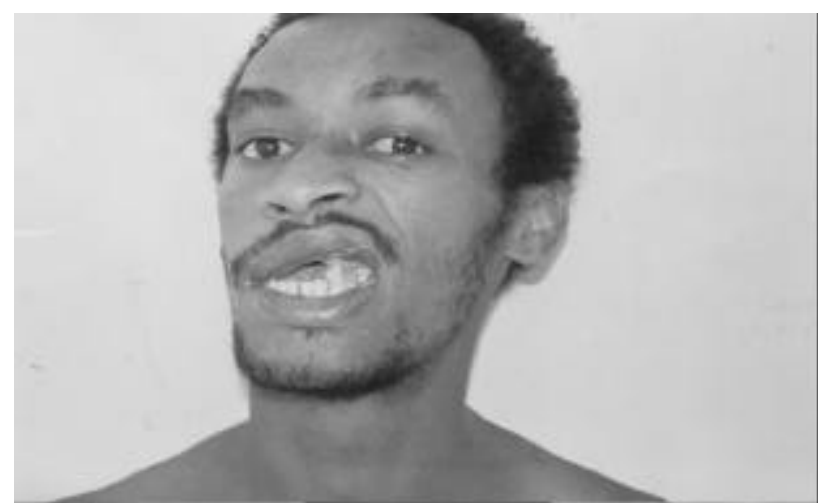

Figure 1 - Patient with facial palsy.

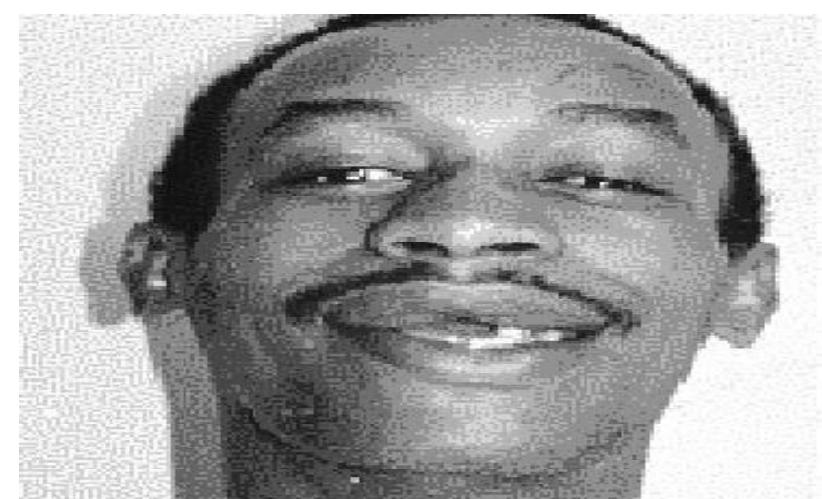

Figure 2 - Patient with no sign of facial palsy 26 days later.

\section{DISCUSSION}

This case report raises the possibility of a possible association between leptospirosis and facial palsy. Obviously, the presence these two conditions in the same patient may be coincidental. Even though neurologic involvement is common in patients with leptospirosis ${ }^{10}$, this infectious disease has not been identified as an important cause of facial nerve palsy. In a search of the MEDLINE database from 1966 to present, only one case report of facial palsy attributed to leptospirosis was found ${ }^{11}$. In this previous report, however, the patient did not present the clinical manifestations more characteristic of the disease. The diagnosis was apparently based on serologic conversion. By contrast, the present case had clinical and laboratory findings characteristic of Weil's disease. In addition, a positive slide agglutination test (SAT) was found nine days after the start of the symptoms. The presence of an initial negative SAT followed by a positive test should be viewed as evidence that the patient's exposure to leptospira was recent. It should be observed that in patients with symptomatic leptospirosis, the conversion of the SAT occurs earlier when compared to the microscopic agglutination test ${ }^{3}$.

It is also important to note that the patient developed facial palsy approximately on the nineteenth day of symptomatic disease, when the clinical manifestations attributed to leptospirosis had subsided. This is consistent with the idea that facial palsy in patients with infectious diseases is mediated by immunological mechanisms ${ }^{9}$. Even though the published data do not permit a conclusion that there is an association between leptospirosis and facial palsy, it is important to be aware of this possibility. A case-control study in which patients with nerve palsy are compared with persons of a control group regarding the odds of seropositivity for leptospirosis is proposed as a fast and cost-effective way to assess this possible association.

\section{REFERENCES}

1. Asbrink E, Olsson I, Hovmark A, Carlsson B. Tick-borne spirochetes as a cause of facial palsy. Clinical Otolaryngology and Allied Sciences 10:279-284, 1985.

2. Balogou AK, Kpemissi E, Nack-Nack M, Anani T, Agboli K, Prince DM, Grunitzky EK. Peripheral facial paralysis (PFP) and HIV infection in Togo. Acta Neurologica Scandinavica 98:200-203, 1998.

3. Brandão AP, Camargo ED, da Silva ED, Silva MV, Abrao RV. Macroscopic agglutination test for rapid diagnosis of human leptospirosis. Journal of Clinical Microbiology 36:3138-3142, 1998.

4. Jackson CG, von Doersten PG. The facial nerve. Current trends in diagnosis, treatment, and rehabilitation. Medical Clinics of North America 83:179-195, 1999.

5. Jain VK, Hilton E, Maytal J, Dorante G, llowite NT, Sood SK. Immunoglobulin $\mathrm{M}$ immunoblot for diagnosis of Borrelia burgdorferi infection in patients with acute facial palsy. Journal of Clinical Microbiology 34:2033-2035, 1996.
6. Johnson PA, Avery C. Infectious mononucleosis presenting as a parotid mass with associated facial nerve palsy. International Journal of Oral and Maxillofacial Surgery 20:193-195, 1991.

7. Keane JR. Bilateral seventh nerve palsy: analysis of 43 cases and review of the literature. Neurology 44:1198-1202, 1994.

8. Mahadeen ZI, Brennan RW, Kothari MJ. Bilateral facial palsy secondary to herpes zoster meningoencephalitis in a HIV-positive woman. Journal of Infection 34:261-262, 1997.

9. Morgan M, Nathwani D. Facial palsy and infection: the unfolding story. Clinical Infectious Diseases 14:263-271, 1992.

10. Romero EC, Billerbeck AE, Lando VS, Camargo ED, Souza CC, Yasuda PH. Detection of Leptospira DNA in patients with aseptic meningitis by PCR. Journal of Clinical Microbiology 36:1453-1455, 1998.

11. Sharma OP, Eltahir N, Roy M. Facial palsy in a patient with leptospirosis: causal or accidental. Sarcoidosis, Vasculitis, and Diffuse Lung Diseases 16:104-106, 1999. 